\title{
Development and Transfer of Immediate Cutaneous Hypersensitivity in Mice Exposed to Aerosolized Antigen
}

Joachim Saloga, Harald Renz, Gideon Lack, Katherine L. Bradley, Julia L. Greenstein, * Gary Larsen, and Erwin W. Gelfand Divisions of Basic Sciences and Pulmonary Medicine, Department of Pediatrics, National Jewish Center for Immunology and Respiratory Medicine, and the Raymond and Beverly Sackler Foundation, Denver, Colorado 80206; and

*Immunologic Pharmaceutical Corporation, Cambridge, Massachusetts 02139

\section{Abstract}

We previously showed that BALB/c mice sensitized to ovalbumin (OVA) by brief daily inhalations of antigen over 10 consecutive days exhibit elevated antigen-specific serum IgE antibody levels and increased airways responsiveness. For the first time, we now show that animals sensitized in this fashion to either OVA or ragweed (RGW) develop immediate hypersensitivity skin test reactions when challenged $2 \mathrm{~d}$ after completion of the sensitization protocol. Skin testing, performed by direct assessment of wheal formation after intradermal injection of allergen, was sensitive and specific, since animals exposed to RGW by inhalation only responded to RGW, and OVA-sensitized animals responded only to OVA. Positive reactions were associated with mast cell degranulation, whereas control injections were not. Since only sensitized IgE high responder BALB/c mice but neither nonsensitized BALB/c mice nor OVA-sensitized IgE low responder SJL/J mice exhibited wheal responses, induction of OVA-specific IgE appeared to be essential for the mediation of OVA-specific immediate hypersensitivity reactions of the skin in this model. Passive cutaneous anaphylaxis (PCA) testing confirmed the presence of antigenspecific IgE in the serum. Mice that developed IgG (predominantly $\operatorname{IgG}_{2 b}$ ) anti-OVA antibodies did not respond to OVA injection, indicating that OVA-specific IgG was not involved in this system. Further support for the role of IgE in the immediate hypersensitivity response included the wheal response to intradermal injection of anti-IgE antibody that occurred in OVA- and RGW-sensitized mice at 10-fold lower concentrations than in nonsensitized BALB/c mice and not in sensitized SJL/J mice. After transfer of mononuclear cells from peribronchial lymph nodes of OVA- or RGW-sensitized BALB/c mice, naive, syngeneic recipients developed antigen-specific IgE and specific immediate hypersensitivity responses, indicating that the local lymphoid tissue at the site of sensitization can transfer responsiveness to these allergens. These results demonstrate for the first time the ability to elicit and study IgE-mediated immediate skin hypersensitivity responses in the mouse and illustrate the association of increased antigen-specific and total serum IgE levels, airways hyperresponsiveness, and antigen-specific immediate cutaneous reactivity after sensitization

Address correspondence to Dr. Erwin W. Gelfand, Department of Pediatrics, National Jewish Center for Immunology and Respiratory Medicine, 1400 Jackson St., Denver, CO 80206.

Received for publication 11 February 1992 and in revised form 10 August 1992.

J. Clin. Invest.

(c) The American Society for Clinical Investigation, Inc.

0021-9738/93/01/0133/08 \$2.00

Volume 91, January 1993, 133-140 to allergen via the airways. (J. Clin. Invest. 1993.91:133-140.)

Key words: immediate cutaneous hypersensitivity • passive transfer • allergen-specific • ovalbumin • ragweed

\section{Introduction}

In vivo animal models for allergic diseases are needed to address questions involving the complex interrelated functions of an intact immune system. Mice are especially suitable for such studies since the components of their immune system are well characterized. Recently, we $(1,2)$ have demonstrated the ability to sensitize mice after antigen exposure through the airways with development of an allergen-specific serum IgE response in IgE-high responder BALB/c mice (3). After nebulization of ovalbumin (OVA), ' an IgE response was elicited without the use of adjuvants (1) and the appearance of a serum IgE antiOVA response was associated with the development of increased airways responsiveness (AR) $(1,2)$.

To further document the importance of $\mathrm{IgE}$ in the mediation of increased $\operatorname{AR}(2,4)$, we also compared the responses of $\mathrm{BALB} / \mathrm{c}$ mice to SJL/J mice, which are known to be low IgE responders (3). Indeed, SJL/J mice did not develop an OVAspecific IgE response (they produced mainly $\operatorname{IgG}_{2 b}$ antibodies) and did not exhibit increases in AR (2). Using this approach, we have now analyzed whether OVA or ragweed ( $R G W$ ) sensitization through the airways and lung is accompanied by sensitization of the skin, a distant organ system, which is frequently involved in allergic responses and is routinely used to test for immediate hypersensitivity (IH) responses.

Assessment of immediate cutaneous hypersensitivity in rodents is usually performed by the cutaneous anaphylaxis method (5-7). Because of a number of technical restrictions, this method has some limitations for routine screening of IH responses. In this report, we demonstrate for the first time the ability to elicit allergen-specific IH responses in mice after exposure to antigen simply by inhalation. The role of IgE in the mediation of the skin test response was delineated by comparing $B A L B / C$ and $S J L / J$ mice, the development of positive responses after intradermal injection of anti-IgE only in sensitized mice and the presence of mast cell degranulation after allergen challenge. The development of positive skin responses correlated with increased AR in sensitized animals. Further, transfer of cells from the peribronchial lymph nodes (PBLN) of sensitized but not nonimmune mice was capable of inducing similar responses in naive, syngeneic recipients, emphasizing

1. Abbreviations used in this paper: AR, airway responsiveness; $\mathrm{IH}$, immediate hypersensitivity; OVA, ovalbumin; MNC, mononuclear cells; PCA, passive cutaneous anaphylaxis; PBLN, peribronchial lymph nodes; RGW, ragweed. 
the potential importance of local lymphoid tissue in the development of systemic allergic responses.

\section{Methods}

Experimental animals. Female BALB/c and SJL/J mice (Jackson Laboratory, Bar Harbor, ME) of about $10 \mathrm{wk}$ of age were maintained under conventional conditions. Their feed was selected to be OVAfree.

Sensitization procedure. Mice were sensitized to OVA (Sigma Chemical Co., St. Louis, MO) as described (1). Briefly, groups of mice were exposed to nebulized OVA ( $1 \% \mathrm{wt} / \mathrm{vol}$ diluted in PBS) for $20 \mathrm{~min}$ daily over a period of 10 consecutive days. Sensitization to RGW (kindly provided by Immulogic, Cambridge, MA) was elicited in the same way, using RGW at a concentration of $70 \mu \mathrm{g} / \mathrm{ml}$ in PBS. The nebulized particle size for both antigens was in the range of $1-5 \mu \mathrm{m}$ as determined by laser nephelometry.

Intradermal skin testing. Before testing, the skin of the belly was carefully shaved with an electric clipper. For each skin test, $20 \mu$ l of test solution were injected intradermally with a 30 -gauge needle from a tuberculin syringe while the skin was stretched taut in animals anesthetized with Avertin $(5 \mathrm{mg} / \mathrm{gm})$. At least a $1.5-\mathrm{cm}$ distance was kept between the sites of injection to avoid confluence of solutions. The concentration of the OVA solution was $500 \mu \mathrm{g} / \mathrm{ml}$ OVA in PBS, pH 7. This OVA concentration was found by previous titration experiments to result in the best ratio of true positive reactions to false positive results, which only occurred at higher concentrations of the solution (data not shown). As controls for specificity, BSA and HSA in PBS (at the same concentrations of protein as OVA) were used, and as negative control, PBS alone was used. RGW was injected in the same way at a concentration of $15 \mu \mathrm{g} / \mathrm{ml}$ and anti-IgE antibody (PharMingen, San Diego, CA) at concentrations of 10 and $100 \mu \mathrm{g} / \mathrm{ml}$. The mast cell degranulating compound $48 / 80$ (Sigma Chemical Co.) at a concentration of $1 \mu \mathrm{g} / \mathrm{ml}$ served as a positive control. Resultant wheal reactions were assessed after 15-20 min. A reaction was scored as positive if the wheal diameter was $>0.3 \mathrm{~cm}$ in any direction measured with a transparent ruler. In general, the wheals were oval in shape and ranged in size from 0.4 to $1 \mathrm{~cm}$. Evaluation of wheal formation was always carried out in a blinded fashion in that the evaluator was unaware of the sensitization status of individual animals.

Passive cutaneous anaphylaxis testing. Pooled serum from 12 OVA-sensitized BALB/c mice was analyzed by the passive cutaneous anaphylaxis (PCA) method using intradermal injection of the serum before application of antigen. Three naive BALB/c mice were injected with $30 \mu \mathrm{l}$ of undiluted serum at two previously marked sites on the shaved abdomen. After $24 \mathrm{~h}$, they were injected at the same sites again with undiluted serum. After an additional $3 \mathrm{~h}$, Evan's Blue (Chroma Gesellschaft, Schmid GmbH \& Co., Stuttgart, Germany) at a concentration of $0.5 \%$ in saline was injected intravenously followed directly by intradermal injection of OVA at a concentration of $500 \mu \mathrm{g} / \mathrm{ml}$ in PBS at one of the marked areas in each mouse. At the other marked site in each animal, PBS alone was injected as a negative control. Compound $48 / 80(1 \mu \mathrm{g} / \mathrm{ml})$ was used as a positive control at a site that was not previously injected with serum and located $>2 \mathrm{~cm}$ from other injection sites. After $30 \mathrm{~min}$, the animals were killed, the skin was inverted, and the responses in terms of infiltration of the blue dye rings around the sites of injection of OVA, PBS, and compound 48/80 were measured. To assess the contribution of IgE to these PCA reactions, the same procedure described above was repeated in three additional naive BALB / c mice after heating of the serum at $56^{\circ} \mathrm{C}$ for $1 \mathrm{~h}$, which inactivates $\operatorname{IgE}(8)$.

Histology. Skin biopsies were taken directly from the site of intradermal injection of the test solutions after assessment of the test result (20 min after intradermal injection), routinely fixed with formalin, dehydrated, and embedded in paraffin. 4- $\mu \mathrm{m}$ thick sections were cut, mounted on regular slides, and stained with Harris-type hematoxylin
(Baxter Scientific, Gibbstown, NJ) for $15 \mathrm{~min}$. Mast cell granules were stained according to the procedure of Lendrum (9) using $1 \mathrm{~g}$ melted phenol (Sigma Chemical Co.) and $5 \mathrm{~g}$ chromotrope (2R; GallardSchlesinger Chemical Mfg. Corp., Carle Place, NY) in $100 \mathrm{ml}$ of distilled water for $30 \mathrm{~min}$.

Determination of serum allergen-specific immunoglobulins. In the sera, total IgE and IgG and allergen-specific IgE and IgG, including IgG subclasses, were measured by ELISA. For measurements of total IgE and IgG round bottom microtiter plates (Immuno Plate II U; Nunc, Naperville, IL) were coated with polyclonal anti-mouse IgE or IgG (The Binding Site, Inc., San Diego, CA) at a concentration of $3 \mu \mathrm{g} / \mathrm{ml}$ in coating buffer respectively. For allergen-specific measurements, the plates were freshly coated with OVA or RGW at a concentration of 20 $\mu \mathrm{g} / \mathrm{ml}$ in $\mathrm{NaHCO}_{3}$ buffer, $\mathrm{pH}$ 9.6. After overnight incubation at $4^{\circ} \mathrm{C}$, plates were washed with PBS and blocked with $0.2 \%$ gelatin buffer, $\mathrm{pH}$ 8.2 for $2 \mathrm{~h}$ at $37^{\circ} \mathrm{C}$.

Serum samples obtained from venous blood of sensitized or control animals were diluted 1:10 in gelatin buffer and added to the plates in duplicate. Standards were added to the plates in a dilution row (dilution factor 2), also in duplicate. For measurements of total IgE and IgG, commercial standards (PharMingen) were used, and readings were referenced to these standards $(\mathrm{ng} / \mathrm{ml})$. For allergen-specific measurements, we compared the readings to allergen-specific standards that were generated in the laboratory and deliberately assigned 1,000 ELISA units $(\mathrm{EU} / \mathrm{ml})$. The generation of the OVA-standard was previously described (1). The RGW-IgE standard was derived by pooling sera from five RGW-sensitized (by inhalation) mice that demonstrated strong RGW-specific skin tests and the RGW-IgG standard was derived as for OVA (1).

After washing with PBS, alkaline phosphatase conjugated monoclonal rat anti-mouse IgE, IgG, and IgG subclass antibodies (PharMingen ) diluted in gelatin buffer were added to the wells and incubated for $2 \mathrm{~h}$ at $37^{\circ} \mathrm{C}$. The reaction was developed with phosphatase substrate (104; Sigma Chemical Co.) and plates were read in a microtiter autoreader (Bio-Rad Laboratories, Pleasanton, CA) at $410 \mathrm{~nm}$. Analysis of ELISA data was performed with the software for the MacIntosh computer (Microplate Manager; Bio-Rad Laboratories), referring to the standards that were added to each plate.

Determination of airways responsiveness. Airway smooth muscle responsiveness was assessed in vitro as described by us $(1,2)$. Briefly, after killing the animal, tracheal smooth muscle segments of about 0.5 $\mathrm{cm}$ in length were cut and placed in Krebs-Henseleit baths suspended by triangular supports transducing the force of contractions. Electrical field stimulations were delivered by a stimulator (model S44 [SIV 5], Grass Instrument Co., Quincy, MA) using 8-V, 2-ms pulse durations and $0.5-40-\mathrm{Hz}$ frequencies. Each challenge was maintained until a peak contractile response was obtained. $40-\mathrm{Hz}$ frequency was established earlier to result in maximal contractions. $\mathrm{ES}_{50}$, the frequency that caused $50 \%$ of the maximal contraction, was calculated from linear plots.

Passive transfer of lymphocytes. For cell transfer experiments, mononuclear cells were prepared under sterile conditions from peribronchial lymph nodes (PBLN) and spleens of nonimmunized BALB/c mice. $2 \mathrm{~d}$ after completion of the 10-d nebulization course, single cell suspensions were prepared by dispersing small tissue pieces through stainless steel meshes. The dispersed cells were separated into mononuclear cells by density gradient centrifugation (Lymphprep; Organon Teknika Corp., Durham, NC) for $15 \mathrm{~min}$ at $1,500 \mathrm{rpm}$ at room temperature. Cells from the interface were washed three times in PBS. The cell concentration was adjusted so that the total volume of the transfer solution did not exceed $0.15 \mathrm{ml}$ per mouse. Desired cell numbers were transferred into syngeneic, naive, age, and sex matched recipients by intravenous infusion into the tail vein. Immediately after the cell transfer, mice were exposed to a single allergen inhalation that was carried out as described above. This single exposure to allergen by itself was not capable of eliciting any response (in terms of IgE antibody or IH). After cell transfer, studies were carried out in recipient mice $2 \mathrm{~d}$ later. 
Flow cytometry. Aliquots of the transferred cell populations were analyzed by flow cytometry for expression of $\mathrm{B}$ and $\mathrm{T}$ cell markers including staining for CD4 and CD8 T cell subsets. For staining, cells were placed in 96-well microtiter plates and washed with staining buffer (PBS supplemented with 2\% heat-inactivated FCS and $0.1 \%$ sodium azide). Then $20 \mu \mathrm{l}$ of $1: 10$ diluted mouse serum were added for blocking of nonspecific binding sites, followed by $20 \mu$ l of biotinylated antibodies (CD3 and CD4 were kindly provided by Drs. J. Kappler and P. Marrack, National Jewish Center, Denver, $C O$ ) diluted in staining buffer. The incubation was carried out on ice for $30 \mathrm{~min}$. After washing, $20 \mu \mathrm{l}$ of diluted phycoerythrin-streptavidin (Tago, Inc., Burlingame, CA) were added to the wells. For CD8 staining we added $20 \mu \mathrm{l}$ of directly FITC-labeled antibody diluted in staining buffer. B cells were identified using the B220 antibody. The second incubation was carried out for $30 \mathrm{~min}$ on ice in the dark. After washing, cell pellets were resuspended in staining buffer and examined using an Epics analyzer (Coulter Electronics, Hialeah, FL).

Data analysis. Immunoglobulin levels are expressed as the mean $\pm S D$. The results of the in vitro assessment of $A R$ are reported as the mean $\pm S E$ of the mean. Student's two-tailed unpaired $t$ test was used to determine the level of difference between sensitized and nonsensitized groups.

\section{Results}

Sensitized $B A L B / c$ mice develop antigen-specific skin test responses. BALB/c mice sensitized to nebulized OVA were administered intradermal injections of OVA at a concentration of $500 \mu \mathrm{g} / \mathrm{ml}$ in PBS. In 31 out of the 37 sensitized BALB/c animals, positive skin test reactions were observed (Table I). A positive skin test reaction was defined by development of a wheal $\geq 0.3 \mathrm{~cm}$ in diameter at the time of assessment, which was usually 15-20 min after injection of the test solution (Fig 1). Overall, the mean wheal size to OVA was $0.5 \mathrm{~cm}( \pm .35)$. The skin included in the wheal had a whiter appearance than the surrounding skin, which was not altered. There was no obvious flare reaction. The wheals actively developed for $\sim 10$ min after injection and persisted for about $30 \mathrm{~min}$.

Similar results were obtained when RGW-sensitized $B A L B / c$ mice were given intradermal injections of RGW at a concentration of $15 \mu \mathrm{g} / \mathrm{ml}$. In 17 out of $18 \mathrm{RGW}$-sensitized mice, positive skin test reactions were elicited (Table I). In general, the wheal sizes to RGW were larger (mean of 0.6 $\mathrm{cm} \pm .39$ ) than seen with OVA. As a control, 22 age and sex
Table I. Allergen-induced Immediate Cutaneous Reactivity

\begin{tabular}{|c|c|c|c|c|c|c|c|}
\hline \multirow[b]{3}{*}{ Mouse strain } & \multirow[b]{3}{*}{ Sensitization } & \multicolumn{6}{|c|}{ Skin test responses } \\
\hline & & \multicolumn{2}{|c|}{ OVA } & \multicolumn{2}{|c|}{ RGW } & \multicolumn{2}{|c|}{ Anti-lgE } \\
\hline & & + & - & + & - & + & - \\
\hline \multirow[t]{3}{*}{ BALB/c } & OVA & 31 & 6 & 0 & 8 & $\begin{array}{c}5 \\
(5)\end{array}$ & $\begin{array}{c}0 \\
(0)\end{array}$ \\
\hline & RGW & 0 & 8 & 17 & 1 & $\begin{array}{c}5 \\
(5)\end{array}$ & $\begin{array}{c}0 \\
(0)\end{array}$ \\
\hline & PBS & 0 & 22 & 0 & 10 & $\begin{array}{c}0 \\
(4)\end{array}$ & $\begin{array}{c}5 \\
\text { (1) }\end{array}$ \\
\hline \multirow[t]{2}{*}{$\mathrm{SJL} / \mathrm{J}$} & OVA & 0 & 7 & ND & ND & $\begin{array}{c}0 \\
(0)\end{array}$ & $\begin{array}{c}5 \\
(5)\end{array}$ \\
\hline & PBS & 0 & 7 & ND & ND & $\begin{array}{c}0 \\
(0)\end{array}$ & $\begin{array}{c}5 \\
(5)\end{array}$ \\
\hline
\end{tabular}

BALB/c and SJL/J mice were sensitized by nebulization of allergens over 10 consecutive days. Skin tests were performed $2 \mathrm{~d}$ after completion of the sensitization protocol by intradermal injection of $20 \mu \mathrm{l}$ of the respective allergen or anti-IgE solution. OVA was injected at a concentration of $500 \mu \mathrm{g} / \mathrm{ml}$ in PBS, RGW at a concentration of 15 $\mu \mathrm{g} / \mathrm{ml}$, and anti-IgE monoclonal antibodies at a concentration of 10 $\mu \mathrm{g} / \mathrm{ml}$ (or $100 \mu \mathrm{g} / \mathrm{ml}$, indicated in parentheses) as indicated. A positive skin test response was defined by active development of a wheal of $\geq 0.3 \mathrm{~cm}$ in diameter. The numbers in the table represent the number of individually tested animals that responded in a positive or negative fashion. ND, not done.

matched BALB/c mice were exposed to PBS alone, the diluent used for nebulization of OVA or RGW, using the same protocol. $2 \mathrm{~d}$ after completion of the PBS nebulization, the animals were skin tested with the same OVA or RGW solutions. In all of these animals, skin tests were negative (Table I), while injection of compound $48 / 80$ as a positive control resulted in the formation of a wheal. To further analyze the specificity of the skin test responses, we also injected the same volume of PBS into the skin of the 37 OVA-sensitized mice and 18 RGW-sensitized mice to exclude nonspecific wheal formation in sensitized mice. In no case was a positive skin test reaction observed as defined above (data not shown).

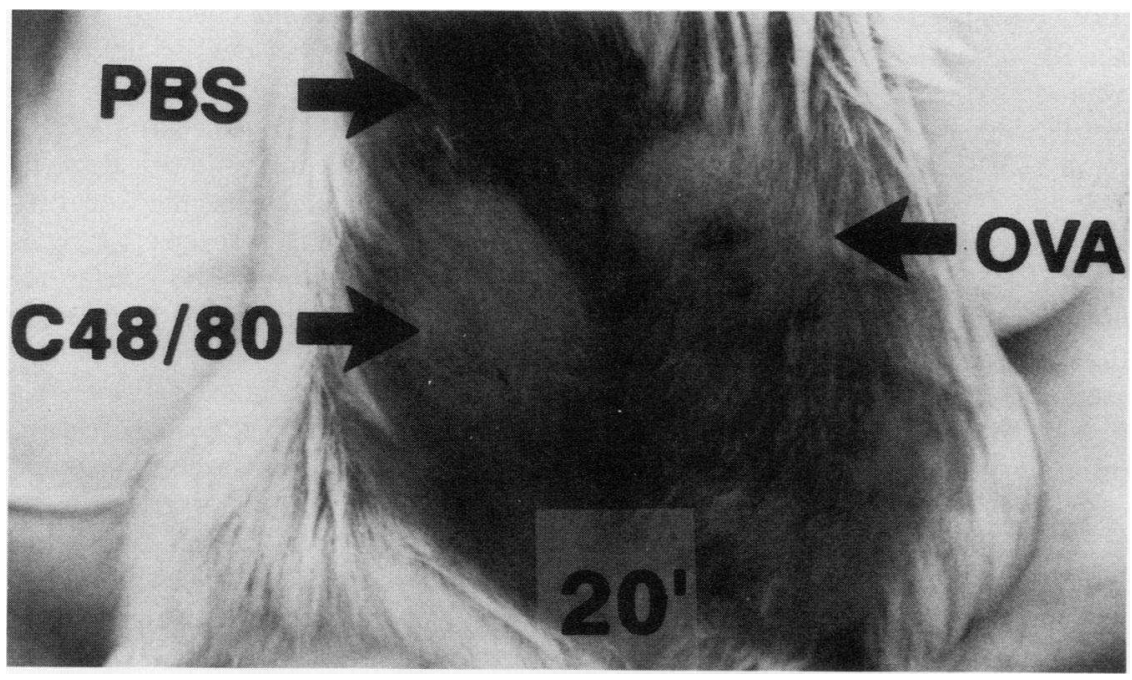

Figure 1. Antigen-specific skin responses alter intradermal injection of $20-\mu$ l test solutions. In OVA-sensitized mice, at the site of injection of OVA ( $500 \mu \mathrm{g} / \mathrm{ml}$ in PBS), active formation of a wheal started at about 10 min, reaching a peak at about $15-20$ min and slowly disappeared thereafter $\left(40^{\prime}\right)$. Injection of PBS did not result in wheal formation in sensitized mice, and injection of mast cell degranulating compound $48 / 80(1 \mu \mathrm{g} / \mathrm{ml})$ resulted in wheal formation in all mice tested. Responses to RGW injection in RGW-sensitized mice had the same appearance and the same kinetics of development. 


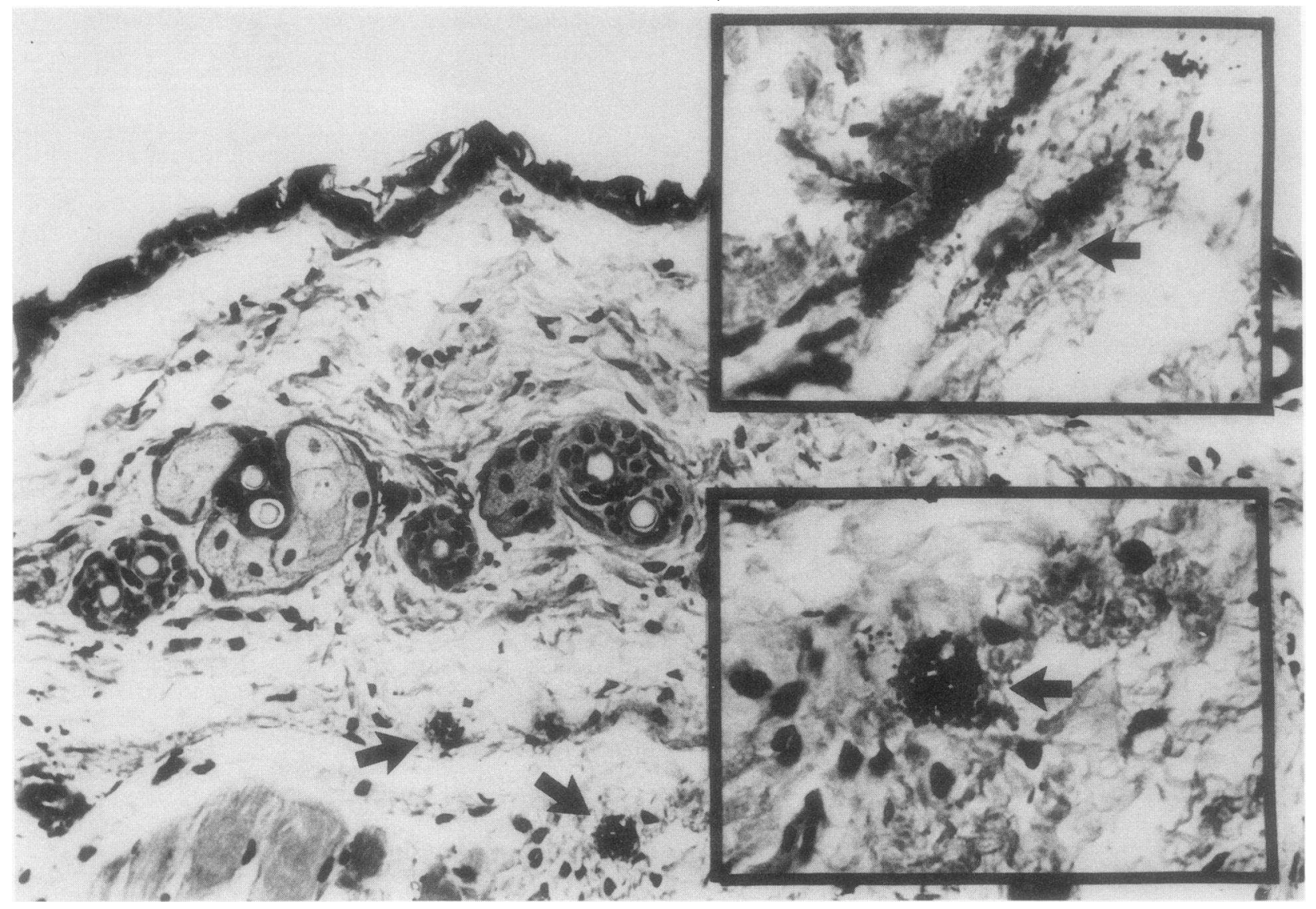

Figure 2. Histological demonstration of mast cell degranulation. Biopsies taken from wheal reactions at their peak revealed mast cell degranulation (arrows) and dermal edema (here $20 \mathrm{~min}$ after injection of $20 \mu \mathrm{l}$ OVA into the skin of an OVA-sensitized BALB/c mouse). Injection of the same volume of PBS into the skin of OVA- or RGW-sensitized mice did not lead to mast cell degranulation nor did injection of OVA or RGW into the skin of nonsensitized mice. Staining was performed with hematoxin and according to Lendrum (8). $\times 300$; insets, $\times 750$.

To exclude reactions that may simply be caused by injection of solutions that contained foreign proteins, we injected OVA-sensitized BALB/c mice with albumins from other species (HSA and BSA) at identical concentrations $(500 \mu \mathrm{g} / \mathrm{ml})$. In no instance were positive skin test reactions elicited under these conditions (data not shown). We also injected the allergen RGW, which elicited positive skin test reactions in RGWsensitized BALB/c mice, into the skin of OVA-sensitized BALB/c mice. As well, we performed skin tests in RGW-sensitized BALB/c mice with OVA. In no animal was a false-positive skin test reaction observed (Table I), confirming the specificity of the responses for exposed antigen. Overall analysis of these data (Table I) revealed a sensitivity for OVA or RGW of $84-94 \%$, a specificity of $100 \%$, a positive predictive value of $100 \%$, and negative predictive value of $79-91 \%$. These data indicate not only the sensitivity and specificity of the skin testing procedure, but demonstrate that sensitization through the lung can result in sensitization of the skin, a distant organ.

Allergen-specific skin test responses are associated with mast cell degranulation. To analyze the mechanism(s) underlying the formation of the wheal response, we studied whether they were accompanied by mast cell degranulation. This was done by staining sections as described originally by Lendrum for eosinophils (9), which also stains granules of basophils and mast cells a dark blue (Fig. 2). Biopsies were taken from OVA- or RGW-sensitized BALB/c mice at a time point when the wheal reaction was at its peak. Dermal edema and extensive mast cell degranulation, evident from the extracellular location of mast cell granules, was consistently observed (Fig 2). Other histopathological changes were not found. To exclude nonspecific effects from injection of the allergen solution, biopsies were taken in the same way from nonsensitized BALB/c mice or from mice injected with PBS. No dermal edema or significant mast cell degranulation could be detected in these animals.

Positive skin test responses are associated with allergenspecific serum IgE levels. To analyze the immunological mechanisms underlying development of antigen-specific wheal responses, we measured total IgE and allergen-specific IgE, IgG, and IgG subclasses in the sera of immunized and nonimmunized mice. The sera were collected immediately before the skin tests were performed $2 \mathrm{~d}$ after completion of the nebulization protocol. In the sera of OVA-sensitized IgE-high responder BALB/c mice, we detected by ELISA a twofold increase in total IgE and the induction of OVA-specific IgE, some OVA-specific IgG, but no $\mathrm{IgG}_{1}$ antibodies (Table II). In the sera of RGW-sensitized BALB/c mice we observed an approximate four- to fivefold increase in total serum IgE and the induction of RGW-specific IgE, as well as $\operatorname{IgG}_{1}$ in contrast to the OVA- system. 


\begin{tabular}{|c|c|c|c|c|c|c|}
\hline \multirow[b]{2}{*}{ Mouse strain } & \multirow[b]{2}{*}{ Sensitization } & \multicolumn{5}{|c|}{ Immunoglobulin levels } \\
\hline & & $\begin{array}{l}\text { Total } \\
\text { IgE }\end{array}$ & IgE & $\begin{array}{c}\operatorname{IgG} \\
\left(\operatorname{IgG}_{1}\right)\end{array}$ & IgE & $\begin{array}{c}\lg G \\
\left(\operatorname{lgG}_{1}\right)\end{array}$ \\
\hline & & $n g / m l$ & $E U / m l$ & $E U / m l$ & $E U / m l$ & $E U / m l$ \\
\hline \multirow[t]{2}{*}{$\mathrm{BALB} / \mathrm{c}$} & $\begin{array}{c}\text { OVA } \\
(n=25)\end{array}$ & $21 \pm 9$ & $1835 \pm 396$ & $\begin{array}{r}215 \pm 24 \\
(<20)\end{array}$ & $<20$ & $\begin{array}{l}<20 \\
(<20)\end{array}$ \\
\hline & $\begin{array}{c}\text { PBS } \\
(n=10)\end{array}$ & $11 \pm 6$ & $<20$ & $\begin{array}{l}<20 \\
(<20)\end{array}$ & $<20$ & $\begin{array}{l}<20 \\
(<20)\end{array}$ \\
\hline $\mathrm{SJL} / \mathrm{J}$ & $\begin{array}{r}\text { OVA } \\
(n=7)\end{array}$ & $<1$ & $29 \pm 18$ & $\begin{array}{c}1333 \pm 217 \\
(45.5 \pm 27.6)\end{array}$ & ND & $\begin{array}{l}\text { ND } \\
\text { (ND) }\end{array}$ \\
\hline
\end{tabular}

Mice were sensitized by nebulization of the allergens over a period of 10 consecutive days. Serum was obtained $2 \mathrm{~d}$ after completion of the sensitization protocol. Serum titers for all antibodies were measured by ELISA; total IgE was measured in $\mathrm{ng} / \mathrm{ml} \mathrm{referring}$ to a commercial standard and allergen-specific antibodies were expressed in ELISA units (EU)/ml referring to laboratory standards for the respective allergen. The depicted data represent the arithmetical mean \pm SD measured in samples from different numbers of animals in each group. ND, not done.

The presence of OVA-specific IgE but not $\operatorname{IgG}_{1}$ was further supported by PCA testing, as only untreated but not heated, pooled serum from OVA-sensitized mice was able to sensitize the skin of naive BALB/c mice before testing with OVA. The two time points ( $27 \mathrm{~h}$ and $3 \mathrm{~h}$ before OVA challenge) were chosen to allow optimal sensitization of the skin by either IgE (long latency) or $\operatorname{IgG}_{1}$ (short latency) antibodies in the serum (8). Therefore, it appears likely that OVA-specific IgE sensitizes dermal mast cells, giving rise to antigen-specific wheal formation.

To further document the role of antigen-specific IgE in the development of these OVA-specific skin reactions, SJL/J mice, which are known to be IgE low responders (3), were exposed in an identical fashion to nebulized OVA. In the sera obtained $2 \mathrm{~d}$ after completion of the OVA-nebulization protocol, no significant induction of OVA-specific IgE was detected, but an early OVA-specific IgG response was elicited (Table II). The $\mathrm{IgG}$ response was comprised mainly of $\mathrm{IgG}_{2 \mathrm{~b}}$ antibodies (data not shown) and did not involve significant increases in $\mathrm{IgG}_{1}$ ( Table II), $\operatorname{IgG}_{2 \mathrm{a}}$, and $\mathrm{IgG}_{3}$ subclasses (data not shown). Total IgE serum levels remained below the detection limit of the ELISA system. Furthermore, when skin tests were performed in sensitized $\mathrm{SJL} / \mathrm{J}$ mice $(2 \mathrm{~d}$ after completion of sensitization), none of the tested mice responded with skin test reactions to OVA (Table I). This indicated that OVA-specific IgG, more specifically $\operatorname{IgG}_{2 b}$, was not able to sensitize dermal mast cells and give rise to wheal reactions in response to the injections of OVA. Injection of compound 48/80 in sensitized SJL/ $\mathrm{J}$ mice resulted in wheal reactions, albeit smaller than in $\mathrm{BALB} / \mathrm{c}$ mice, indicating that mast cells of $\mathrm{SJL} / \mathrm{J}$ mice are functionally intact.

Intradermal injection of anti-IgE antibody results in wheal formation in sensitized $B A L B / c$ mice. Further support for the role of IgE in the skin test reactions was obtained by intradermal injection of $200 \mathrm{ng}(10 \mu \mathrm{g} / \mathrm{ml})$ monoclonal anti-IgE antibody into the skin of OVA- (Table I) or RGW-sensitized (data not shown ) and nonsensitized BALB/c mice and $\mathrm{SJL} / \mathrm{J}$ mice. At this concentration of anti-IgE antibody, wheal reactions were only observed in sensitized BALB/c mice and were not observed in nonimmunized BALB/c animals or in SJL/J mice (Table I). The development of wheals after anti-IgE injection tended to follow the same pattern of formation as observed after allergen injection. To elicit a wheal response in nonsensitized BALB $/ \mathrm{c}$ mice, 10 times higher concentrations of anti-IgE antibody $(2 \mu \mathrm{g})$ were required; at this concentration of antibody SJL mice still remained unresponsive.

Mononuclear cells $(M N C)$ from peribronchial lymph nodes of sensitized $B A L B / c$ mice are able to transfer antigen-specific sensitivity. We described recently that MNC from PBLN of OVA-sensitized BALB/c mice are able to transfer induction of OVA-specific serum IgE and increased AR (1). We also tested whether these cells are able to transfer skin test responsiveness. For this purpose, MNC from PBLN were prepared from OVAor RGW-sensitized BALB/c mice $2 \mathrm{~d}$ after completion of the 10-d nebulization protocol. As controls, we similarly prepared MNC from spleens of PBS-exposed BALB/c mice $2 \mathrm{~d}$ after completion of the 10-d nebulization course, because PBLN of nonsensitized animals are too small to yield sufficient numbers of MNC needed for transfer.

Flow cytometry of the transferred cell types revealed that MNC from PBLN of OVA- or RGW-sensitized BALB/c mice, respectively, consisted of $20-25 \%$ B cells and $62-71 \% \mathrm{~T}$ cells, of which $68-79 \%$ were CD4 positive and $21-32 \%$ CD8 positive; MNC from spleens of control animals contained 22-29\% B cells, $42-51 \%$ T cells, of which $78-88 \%$ were CD4 positive and $12-22 \%$ were CD8 positive.

Intravenous transfer of at least $10 \times 10^{6} \mathrm{MNC}$ cells from PBLN of sensitized BALB/c mice into syngeneic recipients resulted in transfer of antigen-specific positive skin test responsiveness in all recipients when studied $2 \mathrm{~d}$ after transfer of cells (Table III). The kinetics and the size of the observed wheal responses were the same as observed in primary sensitization 
Table III. Transferability of $O V A$ - and $R G W$-specific Immediate Cutaneous Hypersensitivity by MNC from PBLN

\begin{tabular}{|c|c|c|c|c|c|c|}
\hline \multirow{3}{*}{$\begin{array}{c}\text { Donor } \\
\text { sensitization }\end{array}$} & \multicolumn{4}{|c|}{ Skin test response } & \multirow{2}{*}{\multicolumn{2}{|c|}{$\frac{\text { IgE Response }}{\mathrm{EU} / \mathrm{ml}}$}} \\
\hline & \multicolumn{2}{|c|}{ OVA } & \multicolumn{2}{|c|}{ RGW } & & \\
\hline & + & - & + & - & Ova-specific & RGW-specific \\
\hline OVA & 6 & 0 & 0 & 8 & $1181 \pm 296$ & $<20$ \\
\hline RGW & 0 & 6 & 7 & 1 & $<20$ & $1214 \pm 128$ \\
\hline PBS & 0 & 6 & 0 & 8 & $<20$ & $<20$ \\
\hline
\end{tabular}

Donor BALB/c mice were sensitized to OVA or RGW by nebulization over a 10 -d period. $2 \mathrm{~d}$ later, $\mathrm{MNC}\left(10 \times 10^{6}\right)$ from $\mathrm{PBLN}$ were transferred to naive, syngeneic recipients intravenously. Skin tests were performed as in primary sensitized mice by injection of $20 \mu \mathrm{l}$ of the respective allergen two days after cell transfer. Positive skin test responses were noted by active development of a wheal of $\geq 0.3 \mathrm{~cm}$ in diameter. At the same time as skin testing, serum was obtained for allergen-specific IgE, expressed as ELISA units (EU/ml).

animals. MNC from spleens of nonimmunized BALB/c mice were unable to transfer OVA- or RGW-responsiveness in the skin since none of the recipients exhibited a skin test reaction after transfer (Table III). Intravenous transfer of up to five times higher cell numbers $\left(50 \times 10^{6}\right)$ from nonimmunized mice failed to transfer skin sensitivity (data not shown). In parallel to the transfer of skin test reactivity, the capacity to generate allergen-specific IgE was observed in animals receiving $10 \times 10^{6} \mathrm{MNC}$ ( Table III).

OVA-specific immediate hypersensitivity tests correlate with increased $A R$. To correlate immediate skin reactivity with changes in airways responsiveness, we measured AR in BALB/ $\mathrm{c}$ and $\mathrm{SJL} / \mathrm{J}$ mice. Contraction of trachea smooth muscle preparations in response to electrical stimulation was measured in vitro directly after skin testing, $2 \mathrm{~d}$ after completion of the nebulization protocols. As demonstrated previously (2) and confirmed here, only OVA-sensitized BALB/c mice responded with increased $A R$ documented by the decrease in $\mathrm{ES}_{50}$ in this group (Table IV). In addition, OVA-nebulized SJL/J mice did not develop increased AR (Table IV) indicating that exposure to nebulized OVA per se does not induce AR. These data demonstrate the association between development of heightened $\mathrm{AR}$ and positive skin test responses after allergen challenge in the airways.

\section{Discussion}

We have extended our studies in a murine model, where after small-particle nebulization of OVA, animals develop antigenspecific serum IgE and increased airways responsiveness $(1,2)$. In association with these changes, we now demonstrate that sensitized BALB/c mice acquire the capacity to respond to intradermal injection of the sensitizing antigen. The skin test responses to OVA or RGW shared many features with immediate hypersensitivity reactions in the skin of other species, including man. Conventionally, immediate hypersensitivity in rodents has been tested using the method of cutaneous anaphylaxis as initially demonstrated by Ramsdell and Ovary $(5,6)$. This requires intravenous injection of a dye before injection of the allergen and in most applications of this technique, killing of the animal. Exact assessment of the extent of the response
Table IV. Correlation of OVA-specific Cutaneous Hypersensitivity and Airways Hyperresponsiveness

\begin{tabular}{lcrr}
\hline & & \multicolumn{2}{c}{ Skin test response } \\
$\begin{array}{c}\text { Mouse strain } \\
\text { sensitization }\end{array}$ & $\begin{array}{c}\text { OVA } \\
\text { Airways responsiveness } \\
\left(\text { ES }_{50}\right)\end{array}$ & + & - \\
\hline BALB/c & $H z$ & & \\
OVA $(n=20)$ & $2.7 \pm 0.2$ & 17 & 3 \\
PBS $(n=20)$ & $4.2 \pm 0.3^{*}$ & 0 & 20 \\
SJL/J & & & \\
OVA $(n=6)$ & $4.5 \pm 0.5^{*}$ & 0 & 6 \\
PBS $(n=6)$ & $5.4 \pm 1.2^{*}$ & 0 & 6 \\
\hline
\end{tabular}

Mice were sensitized by exposure to nebulized allergen over a period of $10 \mathrm{~d}$. Skin and airways responsiveness was measured $2 \mathrm{~d}$ after completion of the sensitization protocol. $\mathrm{ES}_{50}$ was the stimulation frequency (in $\mathrm{Hz}$ ) that yielded half-maximal contractions of trachea smooth muscle segments prepared from the respective groups. A decrease in $\mathrm{ES}_{50}$ indicates increased airway responsivenss. The $\mathrm{ES}_{50}$ values indicate arithmetic means $\pm S E$. * Indicates values that do not differ significantly $(P>0.05)$ from normal readings in the respective mouse strain.

entails measurement of the diameter of leaked dye on the dermal side of the skin $(6,7)$. The skin test response described in this paper was performed by a direct visualization of wheal formation after intradermal injection of protein antigens similar to the type of skin tests performed in humans to determine immediate hypersensitivity. In rodents, such reports on direct wheal formation are rare and were not analyzed in detail (10, 11). As the animal does not have to be killed to assess the host's response, this approach has many advantages and the results can be correlated with other tests at later time points in the same animal.

The development of a response (wheal formation) was specific $(100 \%)$ in that only the sensitizing antigen could elicit a response. Thus, animals sensitized to OVA responded to OVA and not HSA or BSA. In addition, animals sensitized to either OVA or RGW showed specific reactivity. Wheal formation as a read out was sensitive; $84 \%$ of animals exposed to OVA and 94\% of animals exposed to RGW had positive skin test responses. This approach, therefore, serves as an important means for evaluation of the capacity to demonstrate immediate cutaneous hypersensitivity in mice. Additionally, it is sensitive enough to detect the acquisition of skin sensitization after passive transfer of sensitized cells. $48 \mathrm{~h}$ after transfer of a minimum of $10 \times 10^{6}$ cells, skin sensitization could be detected. In parallel, the capacity to generate OVA- and RGW-specific IgE antibodies was observed. The kinetics of the acquisition of skin sensitization are currently under study.

It appears that wheal formation in mice, similar to humans, is caused by mast cell degranulation. There are, however, some differences between the species. The composition of murine mast cell granules might differ from humans and there are also differences in the anatomy of the skin, which is much thinner in mice. As a result perhaps, the wheals observed in mice are less elevated and not surrounded by a flare response. Additionally, murine $\mathrm{IgG}_{1}$ is capable of sensitizing murine mast cells, independently of IgE (12), although IgG subclass antibodies 
may also interfere with mast cell sensitization by $\operatorname{IgE}(13,14)$. After our OVA-sensitization protocol, $\mathrm{IgG}_{1}$ did not appear to play a role, since BALB/c mice initially developed only low levels of OVA-specific IgG (but no $\operatorname{IgG}_{1}$ ) at the time the IgE response peaks (measured by ELISA), the point when skin testing was carried out. The absence of detectable amounts of $\mathrm{IgG}_{1}$ was also shown using the PCA technique, demonstrating that the sensitizing antibodies were heat labile (8). In RGWsensitized mice, both $\mathrm{IgE}$ and $\mathrm{IgG}_{1}$ allergen-specific antibodies were detected. SJL/J mice, which produce OVA-specific IgG but only very little $\operatorname{IgG}_{1}$ and no $\mathrm{IgE}$ at the time of skin testing, did not develop allergen-specific immediate hypersensitivity skin responses. An additional reason for their failure to mount a positive skin test response may be caused by the interference of the IgG subclass antibodies with the small amounts of IgE and $\operatorname{IgG}_{1}$ produced $(13,14)$. The function of mast cells in both strains was demonstrated to be intact by wheal formation after intradermal injection of the mast cell degranulating compound $48 / 80$, although the resulting wheals in $\mathrm{SJL} / \mathrm{J}$ mice were smaller than in BALB/c mice.

The development of cutaneous hypersensitivity to OVA and RGW was linked to the capacity to develop antigen-specific IgE antibodies at this point in time after sensitization using this protocol. Thus, only sensitized BALB/c mice, or naive recipients of sensitized lymphocytes, developed cutaneous hypersensitivity. The failure of SJL/J mice to develop antigenspecific IgE may reside in their relatively low capacity to synthesize IL-4 (15). PCA reactions, mediated by IgE as well as $\operatorname{IgG}_{1}$, have been described in SJL mice, proving the functional integrity of their mast cells (16). Further support for the role of IgE in our system was obtained by injecting anti-IgE antibody into the skin. This procedure elicits a wheal response by crosslinking mast cell-bound IgE, resulting in cell degranulation. Only OVA- or RGW-sensitized BALB/c mice developed a wheal response after intradermal injection of $200 \mathrm{ng}$ of monoclonal anti-IgE antibody. At this concentration of anti-IgE antibody, nonsensitized BALB/c mice or SJL/J mice failed to respond in this way. At higher (10-fold) concentrations of anti-IgE antibody, the control animals did respond, perhaps implying that there was insufficient IgE on dermal mast cells in these animals to result in triggering of granule release from these cells.

In mice, as well as in humans, IgE production by B cells is stimulated by activated $\mathrm{T}$ cells in the form of physical contact $(17,18)$ and secretion of interleukins $(19,20)$. Interleukin 4 (IL-4) appears essential for inducing the IgE isotype class switch $(19,20)$. In the absence of IL-4 in vitro or in vivo (e.g., $\mathrm{SJL} / \mathrm{J}$ mice), IgE production is limited (15). In the model described here, aerosolization of OVA or RGW results in a marked increase in the size of PBLN, an increase in $\mathrm{CD} 4^{+}$cells in these lymph nodes, and an elevated serum IgE response ( 1 , 2 ). This method of sensitization clearly results in both a local and systemic immune response since both PBLN and spleen demonstrate antigen-reactive $T$ cells as well (1). Based on the ability of the PBLN to rapidly transfer the capacity for recipient mice to develop OVA- and RGW-specific serum IgE antibodies, an immediate hypersensitivity response to OVA or RGW, and increased AR (2), it would appear that the local immune response in the lung may have an important role in the development of increased AR. The mononuclear cells of the PBLN contain both $T$ and $B$ cells and we presume that, at least in part, the transfer of the combination of OVA-reactive $T$ and $B$ cells is responsible for the rapid development of these responses in recipient mice within $2 \mathrm{~d}$ of transfer. However, the exact mechanism in which transfer of immune responsiveness is accomplished is currently under study. Preliminary data on transfer of isolated $\mathrm{T}$ cells indicates their capacity to rapidly induce and regulate IgE production in vivo (manuscript in preparation).

These and earlier studies emphasize the association between sensitization to antigen through the lung, increased airways responsiveness, immediate cutaneous hypersensitivity, and antigen-specific IgE. Although skin test responsiveness to OVA or RGW was associated with the development of specific IgE antibodies, the mechanism underlying the increase in airways responsiveness is less certain (21-26). Further, the role of local versus systemic immunity in the pathophysiology of the changes in the airways remains to be clarified. The ability to monitor changes in airways responsiveness and cutaneous sensitivity and the regulation of IgE production in an animal model provides a unique opportunity for addressing central issues in allergic diseases.

\section{Acknowledgments}

We gratefully acknowledge the excellent technical assistance of Ms. J. Loader for the studies of airway responsiveness and the secretarial work of Ms. G. Wheeler and J. Watkins in the preparation of the manuscript. We would like to thank Dr. Julian Bond and Ms. Liz Gaudet for providing the ragweed extract.

This work was supported by grants PO1-HL36577, AI-26490 and AI-29704 from the National Institutes of Health to E. W. Gelfand and a grant from Immulogic Pharmaceutical Corporation. J. Saloga and $\mathrm{H}$. Renz are supported by grants $S a 483 / 1-1$ and $\operatorname{Re} 737 / 1-1$ from the Deutsche Forschungsgemeinschaft. E. W. Gelfand is Scholar of the Raymond and Beverly Sackler Foundation.

\section{References}

1. Renz, H., H. R. Smith, J. E. Henson, B. S. Ray, C. G. Irvin, and E. W. Gelfand. 1992. Aerosolized antigen exposure without adjuvant causes increased IgE production and increased airways responsiveness in the mouse. J. Allergy Clin. Immunol. 89:1127-1138.

2. Larsen, G. L., H. Renz, J. E. Loader, K. L. Bradley, and E. W. Gelfand. 1992. Airway response to electrical field stimulation in sensitized inbred mice. Passive transfer of increased responsiveness with peribronchial lymph nodes. $J$. Clin. Invest. 89:747-752.

3. Holt, P. G., A. H. Rose, J. E. Batty, and K. J. Turner. 1981. Induction of adjuvant-independent IgE responses in inbred mice. Primary, secondary, and persistent IgE responses to ovalbumin and ovomucoid. Int. Arch. Allergy Appl. Immunol. 65:42-50.

4. Larsen, G. L. 1991. Experimental models of reversible airway obstruction. In The Lung: Scientific Foundations. R. B. Crystal, J. B. West, P. J. Barnes, N. S. Cherniack, and E. R. Weibel, editors. Raven Press, Ltd. New York. p. 953-965.

5. Ramsdell, S. G. 1928. The use of trypan blue to demonstrate the immediate skin reaction in rabbits and guinea pigs. J. Immunol. 15:305-311.

6. Ovary, Z. 1958. Immediate reactions in the skin of experimental animals provoked by antibody-antigen interaction. Prog. Allergy. 5:459-508.

7. Ovary, Z. 1958. Passive cutaneous anaphylaxis in the mouse. J. Immunol. 81:355-357.

8. Watanabe, N., and Z. Ovary. 1977. Antigen and antibody detection by in vivo methods; a reevaluation of passive cutaneous anaphylactic reactions. $J$. Immunol. Methods 14:381-390.

9. Lendrum, A. C. 1944. The staining of eosinophil polymorphs and enterochromatin cells in histological sections. J. Pathol. Bacteriol. 56:441.

10. McCamish, J., and A. A. Benedict. 1963. Studies on immediate cutaneous hypersensitivity in mice. I. Active cutaneous hypersensitivity. J. Immunol. 91:651-657.

11. Chase, M. W. J. 1947. Studies on sensitization of animals with simple chemical compounds; antibodies inducing immediate-type skin reactions. $J$. Exp. Med. 86:489-514.

12. Daëron, M., A. Prouvost-Danon, and G. A. Voisin. 1980. Mast cell membrane antigens and Fc receptors in anaphylaxis. II: functionally distinct receptors for IgG and for IgE on mouse mast cells. Cell. Immunol. 49:178-189.

13. Ovary, Z., N. M. Vaz, and N. L. Warner. 1970. Passive anaphylaxis in 
mice with $\gamma \mathrm{G}$ antibodies. V. Competitive effects of different immunoglobulins and inhibition of reactions with antiglobulin sera. Immunology. 19:715-727.

14. Tigelaar, R. E., N. M. Zaz, and Z. Ovary. 1971. Immunoglobulin receptors on mouse mast cells. J. Immunol. 106:661-672.

15. Mori, A., K. Yamamoto, M. Suko, N. Watanabe, M. Ito, T. Miyuamoto, and H. Okudaira. 1990. Interleukin-4 gene expression in high and low IgE responder mice. Int. Arch. Allergy Appl. Immunol. 92:100-102.

16. De Souza, C. M., L. C. S. Maia, and N. M. Vaz. 1974. Susceptibility to cutaneous anaphylaxis in inbred strains of mice. J. Immunol. 112:1369-1372.

17. DeKruyff, R. H., T. Turner, J. S. Abrams, M. A. Palladino, Jr., and D. T. Umetsu. 1989. Induction of human IgE synthesis by $\mathrm{CD}^{+}{ }^{+} \mathrm{T}$ cell clones. Requirement for interleukin 4 and low molecular weight B cell growth factor. J. Exp. Med. 170:1477-1493.

18. Gascan, H., J.-F. Gauchat, M.-G. Roncarolo, H. Yssel, H. Spits, and J. E. de Vries. 1991. Human B cell clones can be induced to proliferate and to switch to $\mathrm{IgE}$ and $\mathrm{IgG}_{4}$ synthesis by interleukin 4 and a signal provided by activated $\mathrm{CD} 4^{+}$ T cell clones. J. Exp. Med. 173:747-750.

19. Finkelman, F. D., I. M. Katona, J. F. Urban Jr., J. Holmes, J. Ohara, A. S. Tung, J. V. Sample, and W. E. Paul. 1988. Il-4 is required to generate and sustain in vivo IgE responses. J. Immunol. 141:2335-2341.
20. Snapper, C. M., F. D. Finkelman, and W. E. Paul. 1988. Regulation of $\operatorname{lgG}_{1}$ and IgE production by interleukin 4. Immunol. Rev. 102:51-75.

21. Burrows, B., F. D. Martinez, M. Halonen, R. A. Barbee, and M. G. Cline. 1989. Association of asthma with serum IgE levels and skin-test reactivity to allergens. N. Engl. J. Med. 320:271-277.

22. Cartier, A., N. C. Thomson, P. A. Frith, R. Roberts, and F. E. Hargreave. 1982. Allergen-induced increase in non-allergic bronchial reactivity. J. Allergy Clin. Immunol. 70:170-177.

23. O'Byrne, P. M., J. Dolovich, and F. E. Hargreave. 1987. State of art. Late asthmatic responses. Am. Rev. Respir. Dis. 136:740-751.

24. Lemanske, R. F., Jr., E. C. Dick, C. A. Swenson, R. F. Vrtis, and W. W. Busse. 1989. Rhinovirus upper respiratory infection increases airway hyperreactivity and late asthmatic reactions. J. Clin. Invest. 83:1-10.

25. Mohiuddin, A. A., and R. J. Martin. 1990. Circadian basis of the late asthmatic response. Am. Rev. Respir. Dis. 142:1153-1157.

26. Cookson, W. O. C. M., N. H. De Klerk, G. R. Ryan, A. L. James, and A. W. Musk. 1991. Relative risks of bronchial hyper-responsiveness associated with skin-prick test responses to common antigens in young adults. Clin. Exp. Allergy. 21:473-479. 